\title{
Selective Cleavage of $\mathbf{N}$-Acylated $\mathbf{N}, \mathbf{O}$-Acetals with $\mathrm{RCu}_{-}-\mathrm{BF}_{3}$. Synthesis of Cyclic $\alpha$-Alkylated Amides and Carbamates ${ }^{*}$
}

\author{
Catarina Ludwig and Lars-G. Wistrand* \\ Division of Organic Chemistry 3, Chemical Center, University of Lund, PO Box 124, S-221 00 Lund, Sweden
}

Ludwig, C. and Wistrand, L.-G., 1990. Selective Cleavage of $\mathrm{N}$-Acylated $\mathrm{N}, \mathrm{O}$ Acetals with $\mathrm{RCu}-\mathrm{BF}_{3}$. Synthesis of Cyclic $\alpha$-Alkylated Amides and Carbamates. Acta Chem. Scand. 44: 707-710.

Cyclic $\alpha$-methoxylated amides and carbamates are selectively cleaved with $\mathrm{RCu}-\mathrm{BF}_{3}$ to give $\alpha$-alkylated amides and carbamates. Substrates containing a chiral auxiliary (1d and 3d) gave low $(<10 \%)$ degrees of asymmetric induction.

The electrochemical oxidation of amides and carbamates in methanol is one of the most general and efficient electrochemical reactions known. ${ }^{1}$ The products, $\alpha$-methoxylated amides or carbamates, have been shown to be useful intermediates for the synthesis of $\alpha$-substituted amines via nucleophilic attack on the corresponding $\mathrm{N}$-acyliminium ion ${ }^{2}$ (Scheme 1).

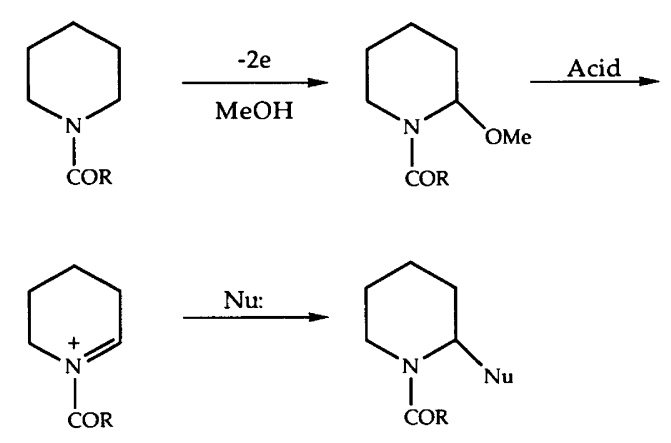

Scheme 1.

A large number of various nucleophiles ( $\mathrm{Nu}$ :) have been used, such as olefins, ${ }^{3}$ enol ethers, ${ }^{4}$ enol esters, malonic and acetoacetic esters ${ }^{5}$ and allyl silanes. ${ }^{6}$ The common denominator for these nucleophiles is that they are all $\pi$-nucleophiles, i.e. they all contain an electron-rich double bond capable of attacking the $N$-acyliminium ion. The corresponding addition of a $\sigma$-nucleophile such as an organometallic reagent (RM) would increase the versatility of the $\alpha$-methoxy amides and carbamates as synthetic intermediates because of the great flexibility in the $\mathbf{R}$ group compared with that of the $\pi$-nucleophiles mentioned

\footnotetext{
* Part 6 in the series Synthetic Applications of Electrochemically Produced $\alpha$-Methoxy Amides. For Part 5, see Thaning, M. and Wistrand, L.-G. J. Org. Chem. In press.

* To whom correspondence should be addressed.
}

above. A necessary requirement for such an organometallic reagent is its stability towards the Lewis or Brønsted acid required for the formation of the $\mathrm{N}$-acyliminium ion. Seebach and co-workers have reported on the cleavage of $\alpha$-methoxy carbamates with Grignard reagents in the absence of a Lewis acid; however, under these conditions, the carbamate was simultaneously transformed into an alkylamide. $^{7}$

Organocopper reagents have been shown to be versatile reagents to effect nucleophilic addition to, and substitution of, a large number of functional groups. Recently it has been reported that the reactivity and selectivity of organocopper reagents can be increased by adding Lewis acids such as boron trifluoride. ${ }^{8}$ For example, Normant and co-workers have reported on the facile cleavage of acetals using $\mathrm{RCu}$ or $\mathrm{R}_{2} \mathrm{CuLi}$ in combination with $\mathrm{BF}_{3} \cdot{ }^{9}$

In this report, we present results from our studies on the reaction of organocopper reagents with cyclic $\alpha$-methoxylated amides and carbamates in the presence of boron trifluoride.

\section{Results and discussion}

Initial experiments on the addition of organocopper reagents to cyclic $\alpha$-methoxylated formamides (1a and 3a) were disappointing. A large number of products were formed, none of which were dominant. Similar results were obtained for $\mathrm{BuCu}, \mathrm{BF}_{3}$ and $\mathrm{Bu}_{2} \mathrm{CuLi}, \mathrm{BF}_{3}$. However, for<smiles>CCCN(C(=O)O)C(C)CC</smiles><smiles>[R]C(C)N(CCCC)C(=O)O</smiles>

$$
1, n=1
$$$$
3, n=2
$$

Scheme 2. 
Table 1. Reaction of $\alpha$-methoxylated amides and carbamates with $\mathrm{RCu}, \mathrm{BF}_{3}$

\begin{tabular}{|c|c|c|c|c|c|}
\hline Entry & Substrate & $\mathrm{R}^{1}$ & $\mathrm{R}^{2}$ in $\mathrm{R}^{2} \mathrm{Cu}$ & Product & Yield $(\%)^{a}$ \\
\hline 1 & $1 a$ & $\mathrm{H}$ & $n-B u$ & $2 a$ & - \\
\hline 2 & $1 b$ & $\mathrm{Me}$ & $n-B u$ & $2 b$ & 65 \\
\hline 3 & $1 c$ & OMe & $\mathrm{n}-\mathrm{Bu}$ & $2 c$ & 86 \\
\hline 4 & 1c & OMe & $\mathrm{n}-\mathrm{Bu}^{b}$ & $2 c$ & $66^{c}$ \\
\hline 5 & 1c & OMe & $\mathrm{n}-\mathrm{Bu}^{d}$ & $2 c$ & $76^{c}$ \\
\hline 6 & $1 c$ & OMe & n-Hept & $2 d$ & 73 \\
\hline 7 & $3 \mathbf{a}$ & $\mathrm{H}$ & $\mathrm{n}-\mathrm{Bu}$ & $4 a$ & - \\
\hline 8 & $3 b$ & $\mathrm{Me}$ & $\mathrm{n}-\mathrm{Bu}$ & $\mathbf{4 b}$ & 55 \\
\hline 9 & $3 c$ & OMe & $\mathrm{n}-\mathrm{Bu}$ & $4 c$ & 87 \\
\hline 10 & $3 c$ & $\mathrm{OMe}$ & n-Hept & 4d & 71 \\
\hline
\end{tabular}

${ }^{a}$ Isolated yields. ${ }^{b} \mathrm{AlCl}_{3}$ was used as the Lewis acid. ${ }^{c}$ Yields were determined by $\mathrm{GLC} .{ }^{d} 2$ equiv. $\mathrm{Bu}_{2} \mathrm{CuLi}_{1} \mathrm{BF}_{3}$ was used.

the corresponding acetamides ( $\mathbf{1 b}$ and $\mathbf{3 b}$ ), a clean conversion into the 2-butyl substituted compounds ( $2 \mathbf{b}$ and $\mathbf{4 b}$ ) was observed (see Table 1, Entries 2 and 8) using 2 equiv. each of $\mathrm{BuCu}$ and $\mathrm{BF}_{3}$. Similarly, the analogous methyl carbamates 1c and 3c gave the corresponding 2-butyl (2c and $\mathbf{4 c}$ ) and 2-heptyl substituted carbamates (2d and 4d). The results are summarized in Table 1 . The best results were obtained with $\mathrm{RCu}, \mathrm{BF}_{3}$; the use of $\mathrm{AlCl}_{3}$ instead of $\mathrm{BF}_{3}$ or $\mathrm{R}_{2} \mathrm{CuLi}, \mathrm{BF}_{3}$ resulted in lower yields of alkylated products. In no case was cleavage of the $\mathrm{C}-\mathrm{N}$ bond of the $\mathrm{N}$-acylated $\mathrm{N}, \mathrm{O}$-acetal observed.

We have also investigated two somewhat different substrates, namely the optically active $\alpha$-methoxylated carbamates 1d and 3d. The sequence anodic methoxylationnucleophilic substitution creates a new chiral center $\alpha$ to the nitrogen, and thus, asymmetric induction by the use of a substrate containing a chiral auxiliary such as 1d and $\mathbf{3 d}$ should be possible. Asymmetric induction in amidoalkylation reactions has been reported by Wanner and coworkers ${ }^{10}$ using a camphanic acid type chiral auxiliary. Compounds 1d and 3d were prepared as 1:1 mixtures of diastereomers by anodic methoxylation of 5 and 6 , respectively. Reaction of $\mathbf{1 d}$ and $3 \mathbf{d}$ with $\mathrm{BuCu}$ or $\mathrm{Bu}_{2} \mathrm{CuLi}$ in the presence of $\mathrm{BF}_{3}$ led to disappointingly low degrees of asym-

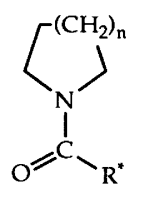<smiles>[R]C(=O)N(CCC)C(C)OC</smiles>

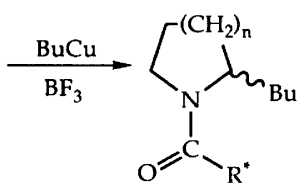

5, $n=1$
6, $n=2$

1d, $n=1$

3d, $n=2$<smiles>[R]#CC[C@H](C)C1C[C@H](C)CC[C@H]1C</smiles>

$2 e, n=1$

4e, $n=2$
Table 2. Reaction of chiral carbamates $1 \mathrm{~d}$ and $3 \mathrm{~d}$ with organocopper reagents.

\begin{tabular}{lllll}
\hline Entry & Substrate & Reagent & Yield (\%) $^{a}$ & d.e. (\%) \\
\hline 1 & 1d & BuCu & 83 & 7 \\
2 & 1d & Bu $_{2} \mathrm{CuLi}$ & $71^{b}$ & 5 \\
3 & 1d & $\mathrm{BuCu}^{c}$ & 91 & 6 \\
4 & 3d & $\mathrm{BuCu}^{b}$ & 74 & 9 \\
5 & 3d & $\mathrm{Bu}_{2} \mathrm{CuLi}$ & 52 & 2 \\
6 & 3d & $\mathrm{BuCu}^{c}$ & 67 & 7 \\
\hline
\end{tabular}

${ }^{a}$ Isolated yields. ${ }^{b}$ Determined by GLC. ${ }^{c}$ Starting from BuMgBr.

metric induction (Table 2). The yields of alkylated products were acceptable, but since separation of the diastereomeric mixtures proved very difficult, this is not a useful method for the synthesis of optically active $\alpha$-alkylated piperidines and pyrrolidines.

From a mechanistic point of view, the attempts at asymmetric induction provided additional information. Separation of the diastereomers of 1d by column chromatography was partially successful. Reaction of such an enriched mixture (diastereomer ratio 80:20) gave an identical diastereomeric excess in the reaction with $\mathrm{BuCu}, \mathrm{BF}_{3}$ compared with that observed for a 1:1 mixture. This observation supports a mechanism involving an intermediary $N$-acyliminium ion as depicted in Scheme 1.

In conclusion, we have shown that cyclic $\alpha$-methoxylated amides and carbamates can easily be converted into the corresponding $\alpha$-alkylated compounds via reaction with $\mathrm{RCu}, \mathrm{BF}_{3}$. However, attempts at asymmetric induction using chiral auxiliaries met with little success. Further work on possible diastereoselective reactions of optically active substrates is in progress and will be the subject of future reports.

\section{Experimental}

General. All chemicals used were of highest commercial quality and were used without further purification. Light petroleum (b.p. $60-80^{\circ} \mathrm{C}$ ) and ethyl acetate, used for chromatography, were distilled before use. $\mathrm{BF}_{3}, \mathrm{Et}_{2} \mathrm{O}$ was distilled before use. $\alpha$-Methoxylated formamides, ${ }^{11}$ acetamides $^{12}$ and methylcarbamates ${ }^{13}$ were prepared according to the reported literature procedures. Reaction mixtures were analyzed by capillary GLC using a Varian 3400 gas chromatograph equipped with a Varian 4270 integrator on a $25 \mathrm{~m} \times 0.25 \mathrm{~mm}$ OV 1701 column and by TLC on commercially available silica gel/ aluminium foil plates. Flash chromatography was performed according to Taber. ${ }^{14}$ ${ }^{1} \mathrm{H}$ NMR spectra were recorded in $\mathrm{CDCl}_{3}$ solutions on a Varian XL 300 or a JEOL PMX 60 machine; $\delta$ in ppm downfield from $\mathrm{Me}_{4} \mathrm{Si}$ as an internal standard. Elemental analysis was carried out by Dornis und Kolbe, Mülheim a.d. Ruhr BRD. High resolution mass spectra were recorded on a VG Trio-2, direct inlet. 
General procedure for the reaction 1 and 3 with organocopper reagents. To a stirred solution of $\mathrm{CuBr}, \mathrm{Me}_{2} \mathrm{~S}^{15}(10$ mmol) in anhydrous $\mathrm{Et}_{2} \mathrm{O}(20 \mathrm{ml})$ was added dropwise BuLi (10 mmol, $2.06 \mathrm{M}$ in hexane) at $-40^{\circ} \mathrm{C}$ under an atmosphere of argon. After being stirred for $30 \mathrm{~min}$, the mixture was cooled to $-70^{\circ} \mathrm{C} . \mathrm{BF}_{3}, \mathrm{Et}_{2} \mathrm{O}(10 \mathrm{mmol})$ was added and stirring was continued for another $5 \mathrm{~min}$. A solution of 1 or $3(5 \mathrm{mmol})$ in anhydrous $\mathrm{Et}_{2} \mathrm{O}(5 \mathrm{ml})$ was added dropwise, and the reaction mixture was allowed to reach ambient temperature. The reaction was quenched with a mixture of concentrated $\mathrm{NH}_{3}$ and satd. aq. $\mathrm{NH}_{4} \mathrm{Cl}$ $(1: 1)$ and stirred for $1 \mathrm{~h}$. The aqueous layer was extracted with $\mathrm{CH}_{2} \mathrm{Cl}_{2}$ and the combined organic phases were washed with satd. aq. $\mathrm{NaHCO}_{3}$, dried $\left(\mathrm{MgSO}_{4}\right)$, filtered and evaporated.

1-Acetyl-2-butylpyrrolidine (2b). The crude product was distilled in a Kugelrohr apparatus at $62^{\circ} \mathrm{C}(0.3 \mathrm{mmHg})$. ${ }^{1} \mathrm{H}$ NMR (300 MHz): $\delta 4.0-4.05(\mathrm{~m}, 0.5 \mathrm{H}), 3.70-3.75(\mathrm{~m}$, $0.5 \mathrm{H}), 3.3-3.55(\mathrm{~m}, 2 \mathrm{H}), 2.04(2 \mathrm{~s}, 1: 1,3 \mathrm{H}), 1.60-1.98$ (m, $5 \mathrm{H}), 1.14-1.60(\mathrm{~m}, 5 \mathrm{H}), 0.87(\mathrm{q}, J 7.2 \mathrm{~Hz}, 3 \mathrm{H})$. MS (high resolution): Found: $\left(M^{+}+1\right) 170.154 \pm 0.006$. Calc. 170.154 .

2-Butyl-1-methoxycarbonylpyrrolidine (2c). The crude product was distilled in a Kugelrohr apparatus at $54^{\circ} \mathrm{C}(0.4$ mmHg). ${ }^{1} \mathrm{H}$ NMR $(300 \mathrm{MHz}): \delta 3.7-3.8(\mathrm{~m}, 1 \mathrm{H}), 3.65(\mathrm{~s}$, $3 \mathrm{H}), 3.3-3.45(\mathrm{~m}, 2 \mathrm{H}), 1.6-1.95(\mathrm{~m}, 5 \mathrm{H}), 1.15-1.4(\mathrm{~m}$, $5 \mathrm{H}), 0.89$ (t, J $6.9 \mathrm{~Hz}, 3 \mathrm{H})$. Anal. $\mathrm{C}_{10} \mathrm{H}_{19} \mathrm{NO}_{2}: \mathrm{C}, \mathrm{H}$.

2-Heptyl-1-methoxycarbonylpyrrolidine (2d). Column chromatography on silica gel using light petroleum/ ethyl acetate (4:1) as the eluant gave pure 2d. ${ }^{1} \mathrm{H}$ NMR (300 $\mathrm{MHz})$ : $3.80-3.93(\mathrm{~m}, 1 \mathrm{H}), 3.70(\mathrm{~s}, 3 \mathrm{H}), 3.26-3.48(\mathrm{~m}$, $2 \mathrm{H}), 1.59-1.97(\mathrm{~m}, 4 \mathrm{H}), 1.16-1.38(\mathrm{~m}, 12 \mathrm{H}), 0.87(\mathrm{t}$, J $6.2 \mathrm{~Hz}, 3 \mathrm{H}$ ). Anal. $\mathrm{C}_{13} \mathrm{H}_{25} \mathrm{NO}_{2}: \mathrm{C}, \mathrm{H}$.

1-Acetyl-2-butylpiperidine (4b). The crude product was distilled in a Kugelrohr apparatus at $66^{\circ} \mathrm{C}(0.3 \mathrm{mmHg})$. ${ }^{1} \mathrm{H}$ NMR (300 MHz): $\delta 4.75$ (br s, $\left.0.5 \mathrm{H}\right), 4.5$ (br d, $0.5 \mathrm{H}), 3.8(\mathrm{br} s, 0.5 \mathrm{H}), 3.55(\mathrm{br} \mathrm{d}, 0.5 \mathrm{H}), 3.07$ (dt, $\left.J_{\mathrm{d}} 2.6, J_{\mathrm{t}} 13.4 \mathrm{~Hz}, 0.5 \mathrm{H}\right), 2.55(\mathrm{t}, J 13.4 \mathrm{~Hz}, 0.5 \mathrm{H}), 2.05$ (s, $3 \mathrm{H}), 1.45-1.7(\mathrm{~m}, 6 \mathrm{H}), 1.1-1.4(\mathrm{~m}, 6 \mathrm{H}), 0.87$ (q, $J 7.4 \mathrm{~Hz}, 3 \mathrm{H}$ ). MS (high resolution): Found: $\left(M^{+}+1\right)$ $184.166 \pm 0.005$. Calc. 184.170.

2-Butyl-1-methoxycarbonylpiperidine (4c). The crude product was distilled in a Kugelrohr apparatus at $60^{\circ} \mathrm{C}(0.4$ mmHg). ${ }^{1} \mathrm{H}$ NMR (300 MHz): $\delta 4.2$ (br s, $\left.1 \mathrm{H}\right), 3.95$ (br d, $1 \mathrm{H}), 3.65(\mathrm{~s}, 3 \mathrm{H}), 2.79\left(\mathrm{dt}, J_{\mathrm{d}} 2.7, J_{\mathrm{t}} 13.4 \mathrm{~Hz}, 1 \mathrm{H}\right)$, $1.5-1.7(\mathrm{~m}, 6 \mathrm{H}), 1.10-1.5(\mathrm{~m}, 6 \mathrm{H}), 0.87(\mathrm{t}, J 7.0 \mathrm{~Hz}$, $3 \mathrm{H}$ ). Anal. $\mathrm{C}_{11} \mathrm{H}_{21} \mathrm{NO}_{2}: \mathrm{C}, \mathrm{H}$.

2-Heptyl-1-methoxycarbonylpiperidine (4d). Column chromatography on silica gel using light petroleum/ ethyl acetate (4:1) as the eluant gave pure 4d. ${ }^{1} \mathrm{H}$ NMR (300
$\mathrm{MHz}): \delta 4.18-4.25(\mathrm{~m}, 1 \mathrm{H}), 3.92-4.04(\mathrm{~m}, 1 \mathrm{H}), 3.68(\mathrm{~s}$, $3 \mathrm{H}), 2.74-2.86(\mathrm{~m}, 1 \mathrm{H}), 1.17-1.70(\mathrm{~m}, 18 \mathrm{H}), 0.87(\mathrm{t}$, $J 6.6 \mathrm{~Hz}, 3 \mathrm{H}$ ). Anal. $\mathrm{C}_{14} \mathrm{H}_{27} \mathrm{NO}_{2}: \mathrm{C}, \mathrm{H}$.

1-Menthyloxycarbonylpyrrolidine (5). A solution of (-)-menthyl chloroformate $(50 \mathrm{mmol})$ in $\mathrm{CH}_{2} \mathrm{Cl}_{2}(30 \mathrm{ml})$ was slowly added to a stirred solution of pyrrolidine (60 mmol) and triethylamine $(80 \mathrm{mmol})$ in $\mathrm{CH}_{2} \mathrm{Cl}_{2}(50 \mathrm{ml})$ at $0{ }^{\circ} \mathrm{C}$. After the reaction had been stirred for $20 \mathrm{~min}$, the mixture was allowed to attain ambient temperature and stirring was continued for another $30 \mathrm{~min}$. The reaction was quenched with $\mathrm{H}_{2} \mathrm{O}$, the aqueous layer was extracted with $\mathrm{CH}_{2} \mathrm{Cl}_{2}$ and the combined organic phases were washed with satd. aq. $\mathrm{NH}_{4} \mathrm{Cl}$, dried $\left(\mathrm{MgSO}_{4}\right)$, filtered and evaporated. The product was purified by column chromatography on silica gel (light petroleum/EtOAc 9:1). Yield: $10.5 \mathrm{~g}(83 \%)$ of 5 as white crystals, m.p. $39-40^{\circ} \mathrm{C}$. $[\alpha]_{\mathrm{D}}^{25}=-77.0^{\circ}(c 1.0$, $\mathrm{MeOH}) .{ }^{1} \mathrm{H}$ NMR (300 MHz): $\delta 4.5\left(\mathrm{dt}, J_{\mathrm{d}} 4.4, J_{\mathrm{t}} 10.8 \mathrm{~Hz}\right.$, $1 \mathrm{H}), 3.35$ (br d, $4 \mathrm{H}), 2.05$ (br d, $1 \mathrm{H}), 1.9-2.0(\mathrm{~m}, 1 \mathrm{H})$, 1.8 (br s, $4 \mathrm{H}), 1.65$ (br d, $2 \mathrm{H}), 1.3-1.55(\mathrm{~m}, 2 \mathrm{H})$, 0.9-1.10 (m, $3 \mathrm{H}), 0.87$ (dd, $J 1.6,7.2 \mathrm{~Hz}, 6 \mathrm{H}), 0.77$ (d, J $7.0 \mathrm{~Hz}, 3 \mathrm{H}$ ). Anal. $\mathrm{C}_{15} \mathrm{H}_{27} \mathrm{NO}_{2}: \mathrm{C}, \mathrm{H}$.

1-Menthyloxycarbonylpiperidine (6). A solution of (-)-menthyl chloroformate $(25 \mathrm{mmol})$ in $\mathrm{CH}_{2} \mathrm{Cl}_{2}(15 \mathrm{ml})$ was slowly added to a stirred solution of piperidine (30 mmol) and triethylamine $(40 \mathrm{mmol})$ in $\mathrm{CH}_{2} \mathrm{Cl}_{2}(25 \mathrm{ml})$ at $0{ }^{\circ} \mathrm{C}$. After being stirred for $20 \mathrm{~min}$, the mixture was allowed to attain ambient temperature, and stirring was continued for another $30 \mathrm{~min}$. The reaction mixture was quenched with $\mathrm{H}_{2} \mathrm{O}$, the aqueous layer was extracted with $\mathrm{CH}_{2} \mathrm{Cl}_{2}$, and the combined organic phases were washed with satd. aq. $\mathrm{NH}_{4} \mathrm{Cl}$, dried $\left(\mathrm{MgSO}_{4}\right)$, filtered and evaporated. The product was purified by column chromatography on silica gel (light petroleum/EtOAc 9:1). Yield: $5.34 \mathrm{~g}(80 \%)$ of 6 as white crystals, m.p. $26.5-27.5^{\circ} \mathrm{C}$. $[\alpha]_{\mathrm{D}}^{25}$ $=-71.6^{\circ}(c 1.0, \mathrm{MeOH}) .{ }^{1} \mathrm{H}$ NMR $(300 \mathrm{MHz}): 4.52(\mathrm{dt}$, $\left.J_{\mathrm{d}} 4.4, J_{\mathrm{t}} 10.8 \mathrm{~Hz}, 1 \mathrm{H}\right), 3.4(\mathrm{~m}, 4 \mathrm{H}), 2.05(\mathrm{br} \mathrm{d}, 1 \mathrm{H})$, 1.8-1.95 (m, $1 \mathrm{H}), 1.3-1.7(\mathrm{~m}, 10 \mathrm{H}), 0.9-1.1(\mathrm{~m}, 3 \mathrm{H})$, $0.87(\mathrm{~m}, 6 \mathrm{H}), 0.77(\mathrm{~d}, J 7.0 \mathrm{~Hz}, 3 \mathrm{H})$. Anal. $\mathrm{C}_{16} \mathrm{H}_{29} \mathrm{NO}_{2}$ : $\mathrm{C}, \mathrm{H}$.

Compounds 5 and 6 were oxidized in $\mathrm{MeOH}$ in an undivided cell using two graphite electrodes with a current density of $9 \mathrm{~mA} \mathrm{~cm}^{-2}$ and $\mathrm{Bu}_{4} \mathrm{NBF}_{4}(0.05 \mathrm{M})$ as the supporting electrolyte. The electrolyses were interrupted after passage of ca. $3 \mathrm{~F} \mathrm{~mol}^{-1}$ as monitored by GLC analysis.

1-Menthyloxycarbonyl-2-methoxypyrrolidine (1d). The crude product was subjected to column chromatography on silica gel, using light petroleum/EtOAc (9:1) as the eluant. Partial separation of the two diastereomeric methoxy compounds was observed according to analysis by GLC. Yield: $57 \%$. ${ }^{1} \mathrm{H}$ NMR $(300 \mathrm{MHz}): \delta 5.0-5.2(\mathrm{~m}, 1 \mathrm{H}), 4.55$ (br s, $1 \mathrm{H}), 3.4-3.5(\mathrm{~m}, 2 \mathrm{H}), 3.3(\mathrm{br} \mathrm{d}, 3 \mathrm{H}), 1.6-2.1(\mathrm{~m}, 8 \mathrm{H})$, $1.31-1.5(\mathrm{~m}, 2 \mathrm{H}), 0.95-1.1(\mathrm{~m}, 3 \mathrm{H}), 0.9(\mathrm{~m}, 6 \mathrm{H}), 0.75$ (m, $3 \mathrm{H})$. 
1-Menthyloxycarbonyl-2-methoxypiperidine(3d). The crude product was subjected to column chromatography on silica gel using light petroleum/EtOAc $(10: 1)$ as the eluant. Yield: $43 \%$. ${ }^{1} \mathrm{H}$ NMR $(60 \mathrm{MHz}): \delta 5.6(\mathrm{br} \mathrm{s}, 1 \mathrm{H}), 4.5-5.1$ (m, $1 \mathrm{H}), 4.2$ (br d, $1 \mathrm{H}), 3.36(\mathrm{~s}, 3 \mathrm{H}), 2.9$ (br d, $1 \mathrm{H})$, 1.1-2.5 (m, $15 \mathrm{H}), 0.9(\mathrm{~m}, 6 \mathrm{H}), 0.7(\mathrm{~s}, 3 \mathrm{H})$.

2-Butyl-1-menthyloxycarbonylpyrrolidine (2e). The crude product was subjected to column chromatography on silica gel using light petroleum/EtOAc (10:1) as the eluant. No separation of the diastereoisomers was achieved. ${ }^{1} \mathrm{H}$ NMR (300 MHz): $\delta 4.5-4.6(\mathrm{~m}, 1 \mathrm{H}), 3.75$ (br s, $1 \mathrm{H}), 3.35$ (br s, $2 \mathrm{H}), 1.55-2.1(\mathrm{~m}, 10 \mathrm{H}), 1.15-1.5(\mathrm{~m}, 7 \mathrm{H}), 0.95-1.1(\mathrm{~m}$, $2 \mathrm{H}), \quad 0.8-0.9(\mathrm{~m}, 9 \mathrm{H}), \quad 0.7-0.9(\mathrm{~m}, 3 \mathrm{H})$. Anal. $\mathrm{C}_{19} \mathrm{H}_{35} \mathrm{NO}_{2}$ : C, $\mathrm{H}$.

2-Butyl-1-menthyloxycarbonylpiperidine (4e). The crude product was subjected to column chromatography on silica gel using light petroleum/EtOAc 10:1 as the eluant. No separation of the diastereoisomers was achieved. ${ }^{1} \mathrm{H}$ NMR $(300 \mathrm{MHz}): \delta 4.5-4.6(\mathrm{~m}, 1 \mathrm{H}), 4.20$ (br s, $1 \mathrm{H}), 3.95$ (br s, $1 \mathrm{H}), 2.8(\mathrm{t}, J 13.1 \mathrm{~Hz}, 1 \mathrm{H}), 2.05(\mathrm{br} \mathrm{d}, 1 \mathrm{H}), 1.8-2.0(\mathrm{~m}$, $1 \mathrm{H}), 0.95-1.8(\mathrm{~m}, 19 \mathrm{H}), 0.85-0.9(\mathrm{~m}, 9 \mathrm{H}), 0.78(\mathrm{~m}$, $3 \mathrm{H}$ ). Anal. $\mathrm{C}_{20} \mathrm{H}_{37} \mathrm{NO}_{2}: \mathrm{C}, \mathrm{H}$.

Acknowledgements. Financial support from the Swedish Natural Science Research Council and the Swedish Board for Technical Development is gratefullly acknowledged. We also wish to thank Mats Berglund of AB Draco, Lund for running the high resolution mass spectra.

\section{References}

1. For reviews, see: Shono, T. Tetrahedron 40 (1984) 811; Wistrand, L.-G. Janssen Chim. Acta 4 (1986) 34.

2. Zaugg, H. E. Synthesis (1984) 85 and 181.

3. Schoemaker, H. E., Dukink, J. and Speckamp, W. N. Tetrahedron 34 (1978) 163.

4. Shono, T., Matsumura, Y. and Tsubata, K. J. Am. Chem. Soc. 103 (1981) 1172.

5. Eberson, L., Nyberg, K. and Malmberg, M. Acta Chem. Scand., Ser. B 37 (1983) 555.

6. Kraus, G. A. and Neuenschwander, K. J. Chem. Soc., Chem. Commun. (1982) 134.

7. Renaud, P. and Seebach, D. Angew. Chem., Int. Ed. Engl. 25 (1986) 843; Seebach, D., Charczuk, R., Gerber, C., Renaud, P., Berner, H. and Schneider, H. Helv. Chim. Acta 72 (1989) 401.

8. For a review, see: Yamamoto, Y. Angew. Chem., Int. Ed. Engl. 25 (1986) 947.

9. Ghribi, A., Alexakis, A. and Normant, J. F. Tetrahedron Lett. 25 (1984) 3075; Ghribi, A., Alexakis, A. and Normant, J. F. Tetrahedron Lett. 25 (1984) 3083.

10. Wanner, K. T. and Kärtner, A. Heterocycles 26 (1987) 921; Wanner, K. T., Kärtner, A. and Wadenstorfer, E. Heterocycles 27 (1988) 2549; Wanner, K. T. and Prasschak, P. Heterocycles 29 (1989) 29.

11. Nyberg, K. and Servin, R. Acta Chem. Scand., Ser. B30 (1976) 640.

12. Mitzlaff, M., Warning, K. and Jensen, H. Liebigs Ann. Chem. (1978) 1713; Palasz, P. D. and Utley, J. H. P. J. Chem. Soc., Perkin Trans. 1 (1984) 807.

13. Shono, T., Hamaguchi, H. and Matsumura, Y. J. Am. Chem. Soc. 97 (1975) 4264.

14. Taber, D. F. J. Org. Chem. 47 (1982) 1351.

15. House, H. O., Chu, C.-Y., Wilkins, J. M. and Umen, M. J. J. Org. Chem. 40 (1975) 1460.

Received December 1, 1989. 